\title{
Reconstruction and in vivo analysis of the extinct tbx5 gene from ancient wingless moa (Aves: Dinornithiformes)
}

\author{
Leon Huynen ${ }^{1}$, Takayuki Suzuki ${ }^{2}$, Toshihiko Ogura ${ }^{3}$, Yusuke Watanabe ${ }^{3}$, Craig D Millar ${ }^{4}$, Michael Hofreiter ${ }^{5,6}$, \\ Craig Smith", Sara Mirmoeini ${ }^{8}$ and David M Lambert ${ }^{{ }^{*}}$
}

\begin{abstract}
Background: The forelimb-specific gene tbx5 is highly conserved and essential for the development of forelimbs in zebrafish, mice, and humans. Amongst birds, a single order, Dinornithiformes, comprising the extinct wingless moa of New Zealand, are unique in having no skeletal evidence of forelimb-like structures.

Results: To determine the sequence of tbx5 in moa, we used a range of PCR-based techniques on ancient DNA to retrieve all nine tbx5 exons and splice sites from the giant moa, Dinornis. Moa Tbx5 is identical to chicken Tbx5 in being able to activate the downstream promotors of fgf10 and ANF. In addition we show that missexpression of moa tbx5 in the hindlimb of chicken embryos results in the formation of forelimb features, suggesting that Tbx 5 was fully functional in wingless moa. An alternatively spliced exon 1 for tbx 5 that is expressed specifically in the forelimb region was shown to be almost identical between moa and ostrich, suggesting that, as well as being fully functional, tbx5 is likely to have been expressed normally in moa since divergence from their flighted ancestors, approximately 60 mya.

Conclusions: The results suggests that, as in mice, moa tbx5 is necessary for the induction of forelimbs, but is not sufficient for their outgrowth. Moa Tbx5 may have played an important role in the development of moa's remnant forelimb girdle, and may be required for the formation of this structure. Our results further show that genetic changes affecting genes other than tbx 5 must be responsible for the complete loss of forelimbs in moa.
\end{abstract}

Keywords: tbx5, Moa, Gene expression, Ancient DNA, Development, Forelimb

\section{Background}

Limb loss by regressive evolution is common in nature with well-known examples being whales, some salamanders, and snakes. Amongst birds, the loss of forelimbs is best represented amongst ratites, with a general reduction in wing size evident in the rhea and ostrich, and a more severe truncation of wings shown in emu, cassowary, kiwi, and elephant bird. Surprisingly, phylogenetically, New Zealand's moa group with the fully winged and flighted tinamou [1], despite having lost almost all skeletal elements associated with the wing. The only evidence that moa once had wings is the presence of a small finger-sized

\footnotetext{
* Correspondence: D.lambert@griffith.edu.au

${ }^{1}$ Environmental Futures Centre, Griffith University, 170 Kessels Road, Nathan Qld 4111, Australia

Full list of author information is available at the end of the article
}

bone, the scapulocoracoid, a fused remnant of the forelimb girdle's coracoid and scapula (Figure 1A, B).

To determine the molecular basis of winglessness in moa, we present the first reconstruction and characterization of an ancient multi-exon gene, $t b x 5$, a highly conserved Tbox motif-containing transcription factor known to be essential for forelimb initiation in nearly all animals. Tbx5 is an essential member of a tightly regulated gene network that includes the $H o x$ genes (reviewed in [2]), $f g f 8$ [3], $f g f 10$ [4-6], ANF [7], and sall4 [8]. Of these, tbx 5 is perhaps the best characterized $[5,6,8,9,10]$. Knockouts of $t b x 5$ in mice, or morpholino-induced $t b x 5$ knockdowns in zebrafish, result in the complete loss of forelimbs $[11,12]$. Similarly, natural occurrences of limblessness in humans and zebrafish have been attributed to mutations in $t b x 5$. In humans, most $t b x 5$ mutations are found in the highly conserved DNA-binding Tbox region and result in Holt-Oram syndrome (HOS), 


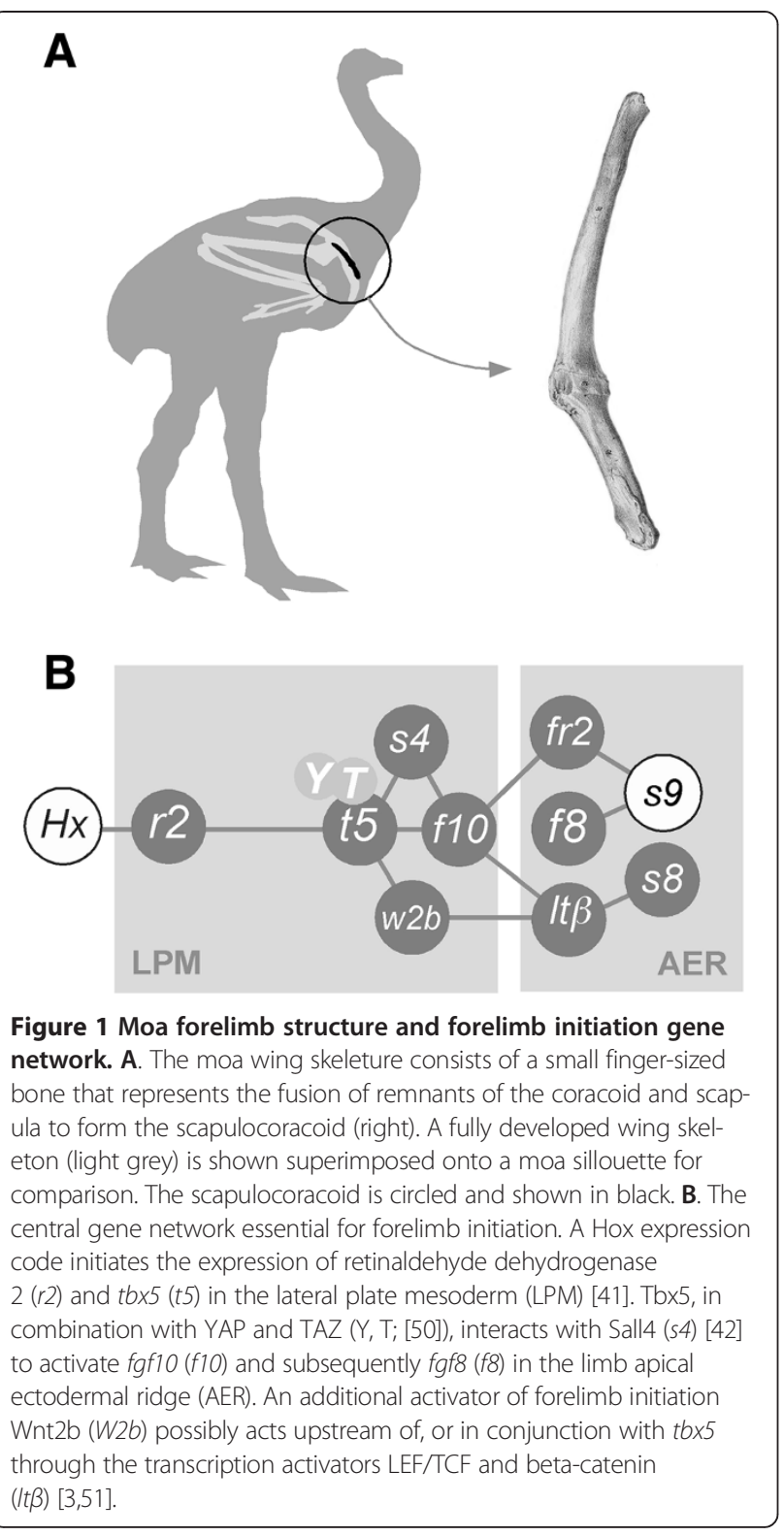

characterized by reduction of the forelimbs and associated heart anomalies [9]. A similar phenotype is shown by the zebrafish tbx5 mutant heartstrings [13].

The spectrum of mutations in Tbx 5 that contribute to Holt-Oram syndrome continues to grow $[9,14,15]$. Tbx 5 mutations have now been found in more than $70 \%$ of patients with a strict clinical diagnosis of HOS [16]. Interestingly, a number of Tbx5 coding sequence mutations result in relatively mild heart defects but severe forelimb abnormalities $[14,17,18]$.

As the forelimb phenotypes of mouse $t b \times 5$ knockouts very closely resemble the phenotype seen in moa, we reconstruct, build, and characterize moa $t b \times 5$ to determine the molecular basis of winglessness in this extinct ratite.

\section{Results}

Moa $t b \times 5$ construction and characterization

To amplify moa $t b x 5$ sequences, primers were designed to chicken $t b x 5$ (NM_204173.1) and ostrich and kiwi $t b \times 5$ mRNA. To obtain the intron/exon boundaries we first obtained these for kiwi using a range of PCR-based methods and then designed primers to these to amplify from moa (Additional file 1: Figures S1-2). Nearly all kiwi $t b x 5$ intron primers successfully amplified from moa aDNA. For a few intron/exon boundaries additional sequence was required from emu, cassowary, ostrich and/or rhea (Figure 2). Moa $t b \times 5$ sequences were obtained as $\sim 120$ bp overlapping fragments from a number of species either by direct sequencing of PCR products or cloned material (Figure 2) (Additional file 1: Figures S3-5, S8). A complete sequence was obtained for the giant moa Dinornis with additional sequence across the highly variable regions of exon 2, exon 6, and exon 8 also being obtained from Megalapteryx didinus (OM Av10049). A single interspecies polymorphic position $(\mathrm{G}>\mathrm{C}$ ) was detected between Dinornis and $M$. didinus at the third base position in coding triplet 18 (Additional file 1: Figure S4). A number of additional sequence variations were detected between moa sequences, but nearly all of these were from clones and were $\mathrm{C}>\mathrm{T}$ transitions commonly the result of aDNA damage. No clear heterozygosity was found amongst moa $t b \times 5$ sequences suggesting the absence of a psuedogene (Additional file 1: Figures S4-5). Moa $t b x 5$ is 521 amino acids long and is identical for the essential 183 aa DNA-binding Tbox region to that of chicken, ostrich, and kiwi. Only two amino acids are unique to moa; an Aspartic acid (D) > Glutamic acid (E) change at amino acid position 3 and a Threonine $(\mathrm{T})>$ Serine $(\mathrm{S})$ change at amino acid position 4 (Additional file 1: Figures S6-7). To verify that these amino acid changes were present on the same molecule, 'long' aDNA amplications were performed to include all the variation detected in exon 2. Intron - exon boundaries of moa $t b \times 5$ all harboured the consensus GT (donor)-AG (acceptor) splice site sequences (Additional file 1: Figure S8). A single intervening sequence change from the consensus $\mathrm{G}$ to $\mathrm{A}$ at position 5 (IVS2 $+5 \mathrm{G}>\mathrm{A}$ ) in Dinornis tbx5 intron 2 has been shown to result in the human fibrinogen gamma gene (FGG) in either retention of the affected intron in the mRNA [19] or deletion of the preceding exon [20]. This sequence change however, is unlikely to have an effect on moa, as this splice site is highly conserved with that from tinamou.

\section{Moa Tbx 5 activates $f g f 10$ and ANF promoters}

Moa or chicken $t b x 5$ in pCAGGS was co-transfected into HEK293T cells with $f g f 10$ or ANF promoter-luciferase constructs and assayed for luciferase activity. Both chicken and moa Tbx 5 were able to activate the $A N F$ and $f g f 10$ promoters with equal efficiency (Figure 3 ). 


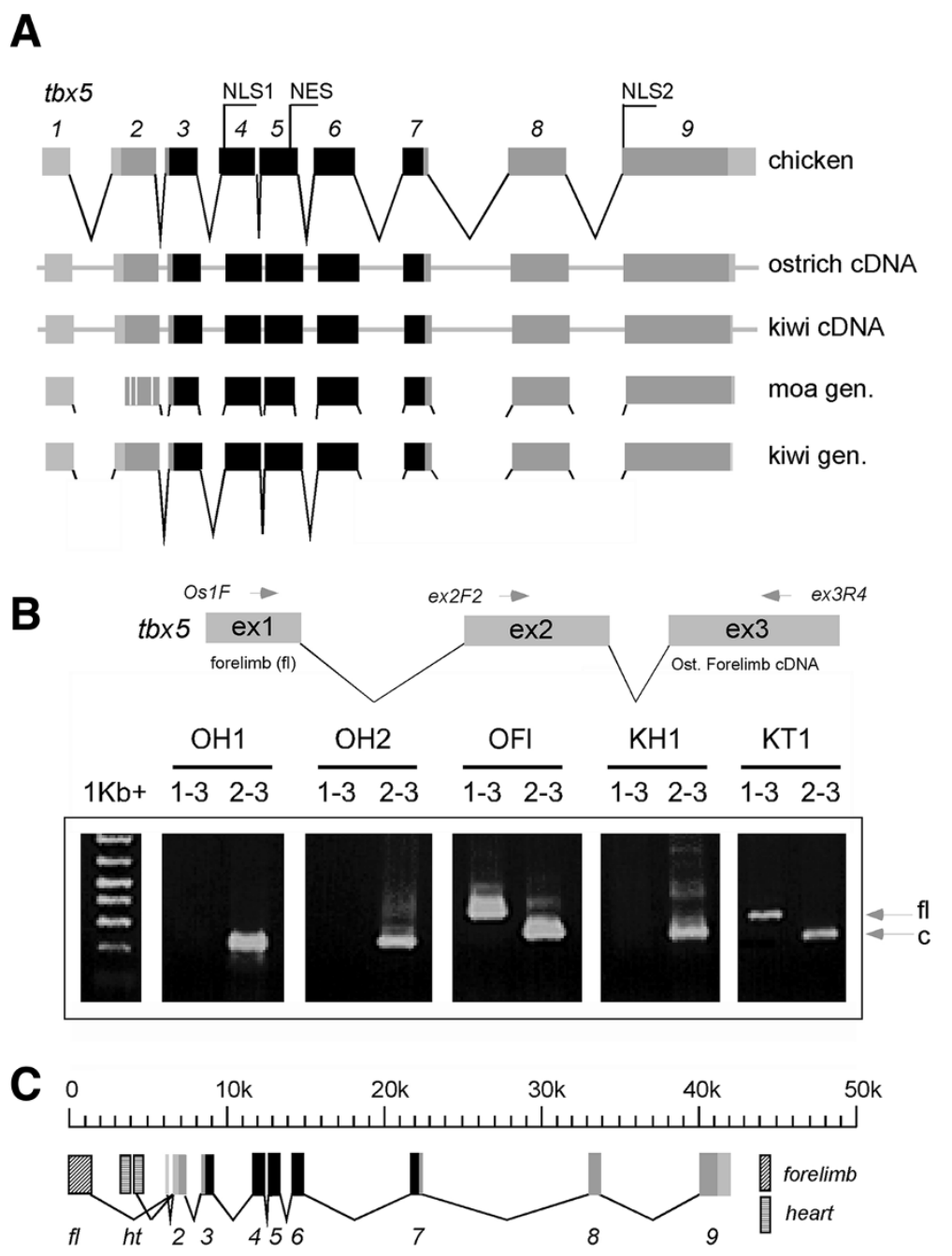

Figure 2 Gene structure of moa tbx5 and detection of forelmb-specific tbx5 transcripts in ostrich and kiwi. A. Comparison of moa tbx 5 gene structure with those of chicken, ostrich, and kiwi. Moa tbx5 exons were identical in length to those of chicken and kiwi. Complete genome data for ostrich was not obtained. The coding region is shown in grey and is 521 amino acids long for all transcripts shown. The 183 amino acid Tbox region is shown in black and is identical between chicken, kiwi, ostrich, and moa. The four amino acids unique to moa $\mathrm{Tb}_{5} 5$ at the $\mathrm{NH}_{2}$ terminus are shown by white vertical lines. The position of Nuclear Localisation Signals 1 and 2 (NLS1, NLS2) and the Nuclear Export Signal (NES) are shown [52,53]. B. A primer (OsF1) designed to tbx5 exon1 sequences obtained from ostrich forelimb cDNA by $5^{\prime}$ RACE was used to try and amplify tbx5 transcripts from heart and forelimb cDNA. Primers to exon 2 and exon 3 amplified the correct sized product from both tissues while the exon1 primer amplified transcripts from forelimb only. OH - ostrich heart CDNA, OFI - ostrich forelimb CDNA, KH - kiwi heart CDNA, KT - kiwi tissue cDNA. C. 5' RACE analysis of A-tailed ostrich heart and forelimb transcripts identified forelimb and heart specific exons. Cross-hatched boxes represent exons expressed in forelimb only. Diagonally lined boxes are exons expressed in heart only. Primer walking of the chicken genome was used to determine the exon boundaries for kiwi and ostrich heart and forelimb tbx5 cDNA. Several clones were sequenced and compared with sequences upstream of chicken tbx5. Two heart-specific exons were located and a single forelimb exon. Analysis of chicken sequences directly upstream of these exons detected no obvious promoter-like sequences.

Moa Tbx5 induces forelimb features in chicken hindlimbs Electroporation of an RCAS moa $t b \times 5$ construct into the presumptive hindlimb region of chicken embryos resulted in the hindlimb developing of a number of forelimb features, including reduced talon size, the production of feathers, and the phenotypic conversion of a hindlimb digit to one that more closely resembles a digit found in the wing (Figure 4, Table 1).
Determination of $t b \times 5$ promoter activity in moa by analysis of forelimb-specific exon 1 sequences

Complementary DNAs from ostrich and kiwi heart and forelimb, respectively, were A-tailed and 5' nested RACE was carried out to isolate $t b x 5$ exon 1 sequences (Additional file 1: Figure S9). Primers designed to exon 1 sequences obtained from forelimb $t b x 5$ only amplified from ostrich or kiwi forelimb RNA (Figure 2). Primer walking using 

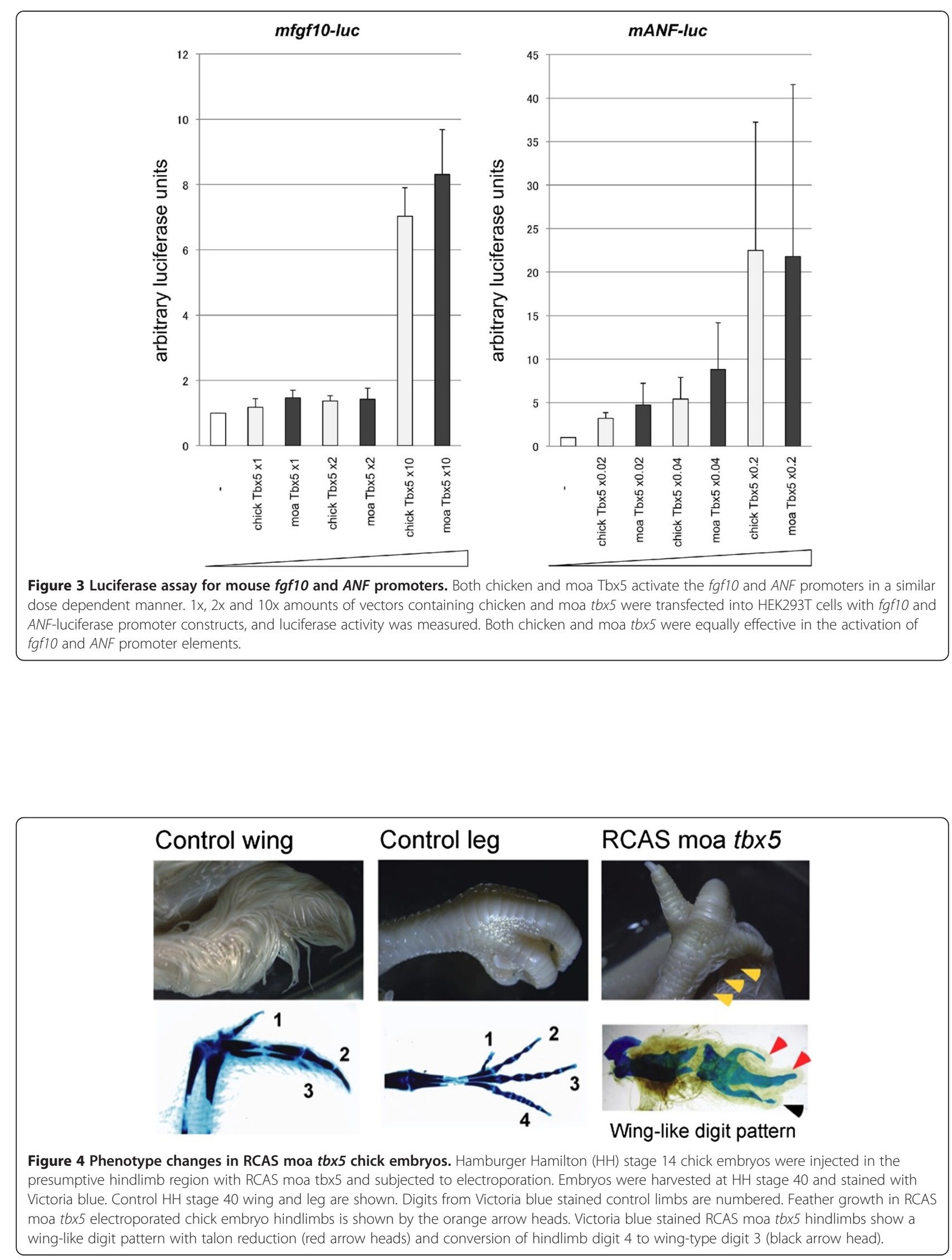


$\begin{aligned} & \text { Table } \mathbf{1} \text { Phenotypes of chick embryo RCAS moa } \mathbf{t b x 5} \text { at } \\
& \text { stage E16 }\end{aligned}$
\begin{tabular}{ll}
\hline Phenotype & Percentage $(\mathbf{n}=\mathbf{9})$ \\
\hline Feather induction in leg & $67 \%(6 / 9)$ \\
Digit 4 converted to wing-type digit 3 & $67 \%(6 / 9)$ \\
Talon reduction & $78 \%(7 / 9)$ \\
\hline
\end{tabular}

the chicken genome allowed the isolation of $~ 350 \mathrm{bp}$ of forelimb-specific exon 1. Isolation of this sequence from emu, cassowary, kiwi, ostrich, rhea, tinamou, and moa shows very little difference between the ratites, with only $4.7 \%$ difference shown between moa and rhea, thought to have diverged approximately 80 mya (Additional file 1: Figures S10-12; [1]).

\section{Discussion/Conclusions}

Loss of flight is common in birds [21]. Studies on Pacific Island rails show that flightlessness can occur rapidly with some birds becoming large and flightless within three million years [22]. For ratites however, it is unknown how long it took for each species to lose flight capabilities. It has been proposed that all lost their flight independently during the Cretaceous Tertiary (KT) boundary approximately 65 mya [1], a theory that challenges the vicariance biogeography model where flightless ratites are presumed to have 'rafted' apart with the breakup of Gondwana [23].

Unlike the other ratites, moa have lost all elements of the forelimb skeleton, save for a finger-like bone, the scapulocoracoid, that once was part of the forelimb girdle. The scapulocoracoid consists of a short coracoid and a long tapering scapula. It is more easily identified in Dinornis, Anomalopteryx, and Pachyornis, but was very small due to the loss of the coracoidal fossa in Megalapteryx, Euryapteryx, and Emeus. Moa do not have a glenoid fossa for articulation to the humerus [24].

The timing of forelimb loss in moa is difficult to determine as a result of limited fossil material. However, by applying mutation rates to phylogenies constructed from Holocene moa, it has been suggested that the last common ancestor of Holocene moa lived 5.8-18.5 mya [25,26]. Furthermore, the discovery of moa leg bones 16-19 mya that are morphologically very similar to those from the Holocene, suggests that these moa were very similar to their later relatives and were also likely to be wingless at that time [27]. As the tinamou/moa split is thought to have occurred 60 mya [1], this places the time taken for moa to develop winglessness at approximately 40 mya. Although by no means conclusive, it is worth noting that a fossil toe bone of Late Cretaceous age (80-65 mya) from New Zealand's North Island may possibly be from a very large bird [28].
Flightlessness and forelimb loss is thought to occur by gradual deminishment as a result of changes in expression of a number of select genes. However, high conservation between the tinamou and moa forelimb-specific exon 1 suggests that in moa $t b x 5$ continues to be expressed in the forelimb region despite possibly 16-19 mys of winglessness. Due to the complex nature of limb development, it has been proposed that limbs can be lost but not regained [29-31]. Collin and Cipriani (2003) [32] go on to suggest that unused genes remain in a functional state in genome for $\sim 6$ my but are almost certain to lose their function at about $10 \mathrm{my}$. This proposal has been challenged by studies on squamates where it has been shown that lost digits at least are recoverable through evolutionary time [33-35]. One reason for this may be that the pleiotropic nature of some genes may act to keep them functional [36]. For example, avian teeth were lost 70-80 million years ago, but the avian genome still harbours the genes required for tooth formation and birds are still able to do so, as has been shown by the recovery of crocodilian-like teeth in mutant talpid $^{2}$ chickens [37]. Similarly, despite having been eyeless for over 1 million years, crosses between different eyeless cavefish populations have been shown to restore vision suggesting that even for complex structures such as eyes, very few loci are required for their redevelopment [38].

The reasons for forelimb-specific expression of $t b \times 5$ in moa are unclear, but may suggest a role for Tbx 5 in maintaining the scapulocoracoid. In flighted birds the scapulocoracoid is always separated into a coracoid and scapula that collectively function to operate flight muscles important for the wing's downward stroke. The retention of a remnant of this structure in moa for so long may well suggest that in moa the scapulocoracoid has evolved a new function. Our results support observations made in mice showing that Tbx5 is necessary for the induction of forelimbs but not sufficient for continued forelimb development $[39,40]$.

\section{Methods}

\section{Ratite bloods, embryos, and tissues}

A $\sim 7$ day post-fertilization kiwi embryo and kiwi embryonic heart were kindly made available to us by Dr. Suzanne Bassett, Otago University, New Zealand. Fertilized ostrich eggs were obtained from Kadesh Ltd, Tajo Ostrich Centre, Kumeu, Auckland, New Zealand, and incubated at $37^{\circ} \mathrm{C}$ with alternate clockwise/anticlockwise $180^{\circ}$ rotations every 12 hours. Ostrich eggs were backlit to measure air-cell size reduction during embryonic growth and embryos were harvested after two weeks. (corresponding to approximate Hamburger Hamilton stage 38, (HH38; [43,44]) when most organ and limb building events are taking place). Emu, rhea, ostrich, and cassowary DNAs were a kind gift from Dr Joy Halverson, Zoogen Services, Sacramento, California, 
US. Kiwi blood was provided by Dr Murray Potter, Massey University, Palmerston North, New Zealand.

\section{Moa samples}

Bone samples, kindly provided by the Otago Museum, the Auckland Institute and Museum, Canterbury Museum, and Massey University, were obtained for $D$. novaezealandiae, $D$. robustus, E. curtus, E. crassus, and M. didinus (see Additional file 1: Table S1).

\section{Ethics statement}

All animal work was conducted according to relevant national and international guidelines. In particular, chick embryo work followed guidelines for animal work enforced by Nagoya University. Chicken embryos were sacrificed at $\mathrm{HH}$ stage 40 . For the ostrich embryo work, given the early stage of sacrifice, no ethics approval was required. All waste material, including chicks, chick eggshell, and yolks were autoclaved and disposed of as industrial waste.

\section{Nucleic acid extraction and manipulation}

Total RNA was isolated from approximately $100 \mathrm{mg}$ of proximal forelimb or heart tissue using TRIzol $^{\circ}$ (Invitrogen) according to the manufacturers instructions. Genomic DNA was recovered from extant ratite blood by standard phenol/chloroform extraction and ethanol precipitation [45]. Ancient DNA (aDNA) was extracted from about $50 \mathrm{mg}$ of moa bone shavings by incubation with rotation overnight at $56^{\circ} \mathrm{C}$ in $0.5 \mathrm{M}$ EDTA/0.01\% Triton X100 with $\sim 2 \mathrm{mg}$ of proteinase $\mathrm{K}$. The mix was then extracted with phenol:chloroform and chloroform and the acqueous layer was purified using a Qiagen Dneasy Blood and Tissue Kit. The silica bound aDNA was eluted with $\sim 40 \mathrm{ul}$ of $0.01 \%$ Triton X100 and stored at $-20^{\circ} \mathrm{C}$.

\section{Reverse transcription of RNA}

Approximately 5 ug of total RNA was reverse transcribed at $41^{\circ} \mathrm{C}$ for $60 \mathrm{~min}$ in $20 \mathrm{ul}$ volumes with random 7-mer or oligodT primers and purified by phenol:chloroform extraction and ethanol precipitation.

\section{Polymerase Chain Reaction (PCR)}

DNA was amplified from approximately $1-20$ ng of DNA as outlined in [46]. A number of PCR-based methods were used to obtain the kiwi tbx5 intron/exon boundaries required to allow primer design for moa amplification. These included: Single primer PCR - A single primer was used in a standard PCR reaction at low annealing temperatures for one cycle to allow random priming and then amplified for $\sim 35$ cycles with the annealing temperature set at the primer's $\mathrm{T}_{\mathrm{m}}$. Hairpin primer ligation $P C R$ - hairpin primers containg a PstI compatible overhang were ligated to PstI-digested DNA before standard PCRs were carried out using the hairpin primer and a $t b \times 5$-specific primer. Medium range $P C R$ - amplification across the smaller $t b x 5$ introns was carried out usng Elongase (Invitrogen) or Expand Long Template PCR System (Roche) as outlined by the manufacturer. Inverse PCR - Inverse PCR was carried out to obtain intron sequences directly from moa. Biefly, moa aDNA was denatured, then dephosphorylated with shrimp alkaline phosphatase (SAP) before fresh phosphates were added with T4 Polynucleotide Kinase. The aDNA was then circularised with Circligase ${ }^{\mathrm{TM}}$ ssDNA Ligase (Epicentre ${ }^{\circ}$ ) and subjected to rolling circle amplification using Templify ${ }^{\mathrm{TM}}$ (Amersham). The amplified aDNA was then subjected to standard PCR using inverse primers.

\section{Construction strategy for moa tbx5}

To isolate moa $t b \times 5$ sequences we initially obtained full-length $t b x 5 \mathrm{cDNA}$ sequences for kiwi and ostrich. Comparison with the chicken genome identified the intron/exon boundaries and primers were then designed to recover moa $t b \times 5$ exon sequences. To obtain moa $t b \times 5$ intron/exon boundaries, these boundaries were first isolated from kiwi. Primers were then designed to kiwi $t b x 5$ intron sequences and conserved ostrich/kiwi/chicken $t b x 5$ exon sequences to obtain moa $t b x 5$ intron/exon boundary sequences. Most primers designed to kiwi $t b x 5$ intron sequences successfully amplified from moa aDNA. For a few introns however, primers successful for amplification from moa required additional intron sequences from rhea, and/or ostrich.

\section{Nested 5' RACE}

Total RNA isolated from embryonic ostrich and kiwi forelimb and kiwi heart were A-tailed with terminal transferase (Invitrogen) and amplified with H5FdT (5'AATCGGACAAACTGGTCCTTGCAACdT 20 ) and ex2R2 (5'- GGTGAGCGACTTGCTGGTG), followed by H5F (5'AATCGGACAAACTGGTCCTTGCAAC) and ex2R3 (5'- CAAAGCCTTCCTCCGTAT). Amplified products were TA cloned into pGEM ${ }^{\circ} \mathrm{T}$-Easy (Promega) and sequenced with m13F (5'-TGTAAAACGACGGCCAGT) or m13R (5'-CAGGAAACAGCTATGACC). Full-length forelimb-specific exon 1 transcripts were then obtained by cDNA walking using primers designed to conserved upstream regions of the chicken genome.

\section{Sequencing}

PCR products were purified by centrifugation through dry Sephacryl S200HR, sequenced using ABI BigDye ${ }^{\circ}$ Terminator v3.1 chemistry, then analysed and aligned in Sequencher ${ }^{\mathrm{TM}} 5.0$ (Gene Codes Corporation). 


\section{Ancient DNA procedures}

In accordance with criteria suggested for the verification of aDNA sequences [47], a number of samples were extracted and sequenced at a separate ancient DNA facility at Massey University, Auckland, New Zealand.

\section{Activation of $f g f 10$ and ANF promoters by moa Tbx5}

The ability of moa Tbx 5 to bind to and activate downstream $f g f 10$ and $A N F$ promoters was determined using a luciferase assay. HEK293T cells were seeded into 24-well plates at a density of $5 \times 10^{4}$ cells/well twenty four hours before transfection. The following vectors were transfected into HEK293T cells using XtremeGENE HP (Roche); $6 \mathrm{~kb}$ of mouse sequence immediately upstream of $f g f 10$ [6], or $0.7 \mathrm{~kb}$ of mouse sequence immediately upstream of the ANF promoter [7], both fused to luciferase, pCAGGS containing chick or moa $t b \times 5, \mathrm{CMX}-\beta$-galactosidase, and an empty control vector (pcDNA3.1). Forty-eight hours after transfection, the cells were lysed, and luciferase activity was measured using a Luminescencer-JNR (ATTO). $\beta$ galactosidase activities were measured to standardize the efficiency of transfection. Results are expressed as the average of three samples including standard deviation.

\section{Miss-expression of moa tbx5 in chicken}

Electroporation into the chick hindlimb field was carried out as described previously [48]. Briefly, $2 \mathrm{ug} / \mathrm{ml}$ of RCASmoa $t b x 5$ plasmid was injected into the prospective hindlimb field at Hamburger Hamilton $(\mathrm{HH})$ stage 14 by glass capillary. Electric pulses $(8 \mathrm{~V}, 60 \mathrm{~ms}$ pulse-on, $50 \mathrm{~ms}$ pulseoff, three repetitions) were applied using an CUY21-EDIT electroporator (NAPA GENE) with platinum electrodes. Electroporated embryos were harvested at $\mathrm{HH}$ stage 40 and stained with Victoria blue. Victoria blue staining was carried out as described in [49].

\section{Availability of supporting data}

Supporting tables and figure are available as additional files. Tbx 5 sequences are deposited in NCBI's GenBank [GenBank Acc Nos. KJ584152-KJ584161].

\section{Additional file}

\section{Additional file 1: Moa tbx5; materials, methods and sequences.}

Detailed descriptions of materials and methods used, nucleotide and amino acid sequences.

\section{Competing interests}

The authors declare that they have no competing interests.

\section{Authors' contributions}

$\mathrm{LH}, \mathrm{TS}, \mathrm{TO}, \mathrm{YW}$, and SM carried out the molecular genetic studies. $\mathrm{LH}, \mathrm{DML}$, CDM, CS, and $\mathrm{MH}$ helped conceive the study and participated in its design and coordination, and helped to draft the manuscript. All authors read and approved the final manuscript.

\section{Acknowledgements}

Grateful thanks to Paul Scofield (Canterbury Museum) and Brian Gill (Auckland Museum) for assistance. Thanks to Tim Heupink for helpful comments. This work was carried out with support from the Australian Research Council (Grant number DP110101364; The molecular evolution of wings in ratites).

\section{Author details}

${ }^{1}$ Environmental Futures Centre, Griffith University, 170 Kessels Road, Nathan Qld 4111, Australia. ${ }^{2}$ Division of Biological Science, Nagoya University, Nagoya 464-8602, Japan. ${ }^{3}$ Institute of Development, Aging and Cancer (IDAC), Tohoku University, Sendai 980-8575, Japan. ${ }^{4}$ Allan Wilson Centre for Molecular Ecology and Evolution, School of Biological Sciences, University of Auckland, Private Bag 92019, Auckland, New Zealand. ${ }^{5}$ Department of Biology, University of York, York YO10 5DD, UK. ${ }^{6}$ Faculty of Natural Sciences, University of Potsdam, 14476 Potsdam, Germany. ${ }^{7}$ Murdoch Children's Research Institute, Royal Children's Hospital, Flemington rd Parkville, Victoria 3052, Australia. ${ }^{8}$ Institute of Natural Sciences, Massey University, Auckland 0632, New Zealand.

Received: 15 February 2014 Accepted: 25 March 2014

Published: 14 May 2014

\section{References}

1. Phillips MJ, Gibb GC, Crimp EA, Penny D: Tinamous and moa flock together: mitochondrial genome sequence analysis reveals independent losses of flight among ratites. Syst Biol 2009, 59:90-107.

2. Zakany J, Duboule D: The role of Hox genes during vertebrate limb development. Curr Op Genet Dev 2009, 17:359-366.

3. Moon AM, Capecchi MR: Fgf8 is required for outgrowth and patterning of the limbs. Nat Genet 2000, 26:455-459.

4. Min H, Danilenko DM, Scully SA, Bolon B, Ring BD, Tarpley JE, DeRose M, Simonet S: Fgf-10 is required for both limb and lung development and exhibits striking functional similarity to Drosophila branchless. Genes Dev 1998, 12:3156-3161.

5. Ng JK, Kawakami Y, Buscher D, Raya A, Itoh T, Koth CM, Rodriguez Esteban C, Rodriguez-Leon J, Garrity DM, Fishman MC, Izpisua Belmonte JC: The limb identity gene Tbx5 promotes limb initiation by interacting with Wnt2b and Fgf10. Development 2002, 129:5161-5170.

6. Agarwal P, Wylie JN, Galceran J, Arkhitko O, Li C, Deng C, Grosschedl R, Bruneau BG: Tbx5 is essential for forelimb bud initiation following patterning of the limb field in the mouse embryo. Development 2003, 130:623-633.

7. Argentin S, Ardati A, Tremblay S, Lihrmann I, Robitaille L, Drouin J, Nemer M: Developmental stage-specific regulation of atrial natruiretic factor gene transcription in cardiac cells. Mol Cell Biol 1994, 14:777-790.

8. Koshiba-Takeuchi K, Takeuchi JK, Arruda EP, Kathiriya IS, Mo R, Hui CC, Srivastava D, Bruneau BG: Cooperative and antagonistic interactions between Sall 4 and Tbx5 pattern the mouse limb and heart. Nat Genet 2006, 38:175-183.

9. Ghosh TK, Packham EA, Bonser AJ, Robinson TE, Cross SJ, Brook JD: Characterization of the Tbx5 binding site and analysis of mutations that cause Holt-Oram syndrome. Hum Mol Genet 2001, 10:1983-1994.

10. Takeuchi JK, Koshiba-Takeuchi K, Suzuki T, Kamimura M, Ogura K, Ogura T: Tbx5 and Tbx4 trigger limb initiation through activation of the Wnt/Fgf signalling cascade. Development 2003, 130:2729-2739.

11. Bruneau BG, Nemer G, Schmidt JP, Charron F, Robitaille L, Caron F, Conner DA, Gessler M, Nemer M, Seidman CE, Seidman JG: A murine model of Holt-Oram syndrome defines roles of the T-Box transcription factor Tbx5 in cardiogenesis and disease. Cell 2001, 106:709-721.

12. Ahn D, Kourakis MJ, Rohde LA, Silver LM, Ho RK: T-box gene tbx5 is essential for formation of the pectoral limb bud. Nature 2002, 417:754-758.

13. Garrity DM, Childs S, Fishman MC: The heartstrings mutation in zebrafish causes heart/fin Tbx5 deficiency syndrome. Development 2002, 129:4635-4645.

14. Brassington AME, Sung SS, Toydemir RM, Le T, Roeder AD, Rutherford AE, Whitby FG, Jorde LB, Bamshad MJ: Expressivity of Holt-Oram syndrome is not predicted by Tbx5 genotype. Am J Hum Genet 2003, 73:74-85.

15. Borozdin W, Bravo Ferrer Acosta AM, Bamshad MJ, Botzenhart EM, Froster UG, Lemke J, Schinzel A, Spranger S, McGaughran J, Wand D, Chrzanowska $\mathrm{KH}$, Kohlhase J: Expanding the spectrum of TBX5 mutations in Holt-Oram 
syndrome: detection of two intragenic deletions by quantitative real time PCR, and report of eight novel point mutations. Hum Mutat 2006, 27:975-976

16. Mori AD, Bruneau BG: Tbx5 mutations and congenital heart disease: Holt-Oram syndrome revealed. Curr Opin Cardiol 2004, 19:211-215.

17. Basson CT, Huang T, Lin RC, Bachinsky DR, Weremowicz S, Vaglio A, Bruzzone R, Quadrelli R, Lerone M, Romeo G, Silengo M, Pereira A, Krieger J, Mesquita SF, Kamisago M, Morton CC, Pierpont ME, Müller CW, Seidman JG, Seidman CE: Different Tbx5 interactions in heart and limb defined by Holt-Oram syndrome mutations. Proc Natl Acad Sci U S A 1999, 96:2919-2924.

18. Isphording D, Leylek AM, Yeung J, Mischel A, Simon H-G: T-box genes and congenital heart/limb malformations. Clin Genet 2004, 66:253-264.

19. Margaglione M, Santacroce $R$, Colaizzo D, Seripa D, Vecchione $G$, Lupone MR, De Lucia D, Fortina P, Grandone E, Perricone C, Di Minno G: A G-to-A mutation in IVS-3 of the human gamma fibrogen gene causing afibrinogenemia due to abnormal RNA splicing. Blood 2000, 96:2501-2505.

20. Asselta R, Duga S, Simonic T, Malcovati M, Santagostino E, Giagrande PL, Mannucci PM, Tenchini ML: A fibrinogenemia: first identification of a splicing mutation in the fibrogen gamma chain gene leading to a major gamma chain truncation. Blood 2000, 96:2496-2500.

21. McCall RA, Nee S, Harvey PH: The role of wing length in the evolution of avian flightlessness. Evol Ecol 1998, 12:569-580.

22. Slikas B, Olson SL, Fleischer RC: Rapid, independent evolution of flightlessness in four species of Pacific Island rails (Rallidae): an analysis based on mitochondrial sequence data. J Avian Biol 2002, 33:5-14.

23. Cracraft J: Phylogeny and evolution of the ratite birds. Ibis 1974, 116:494-521.

24. Worthy $\mathrm{TH}$, Holdaway RN: The lost world of the moa: Canterbury University Press. New Zealand: Christchurch; 2002.

25. Baker AJ, Huynen LJ, Haddrath O, Millar CD, Lambert DM: Reconstructing the tempo and mode of evolution in an extinct clade of birds with ancient DNA: the giant moas of New Zealand. Proc Natl Acad Sci U S A 2005, 102:8257-8262.

26. Bunce M, Worthy TH, Phillips MJ, Holdaway RN, Willerslev E, Haile J, Shapiro B, Scofield RP, Drummond A, Kamp PJ, Cooper A: The evolutionary history of the extinct ratite moa and New Zealand Neogene paleogeography. Proc Natl Acad Sci U S A 2009, 106:20646-20651.

27. Tennyson AJD, Worthy TH, Jones CM, Scofield RP, Hand SJ: Moa's Ark: Miocene fossils reveal the great antiquity of moa (Aves: Dinornithiformes) in Zealandia. Rec Aust Mus 2010, 62:105-114

28. Scarlett RJ, Molnar: Terrestial bird or dinosaur phalanx from the New Zealand Cretaceous. NZ J of Zoology 1984, 11:271-275.

29. Gans C: Tetrapod limblessness: evolution and functional corollaries. Am Zool 1975, 15:455-467.

30. Greer AE: Limb reduction in squamates: identification of the lineages and discussion of the trends. J Herpetol 1991, 25:166-173.

31. Whiting AS, Bauer AM, Sites JW: Phylogenetic relationships and limb loss in sub-Saharan African scincine lizards (Squamata: Scincidae). Mol Phylogen Evol 2003, 29:582-598.

32. Collin R, Cipriani R: Dollo's law and the re-evolution of shell coiling. Proc Royal Soc B 2003, 270:2551-2555

33. Skinner S, Lee MSY, Hutchinson MN: Rapid and repeated limb loss in a clade of scincid lizards. BMC Evol Biol 2008, 8:310.

34. Brandley MC, Huelsenbeck JP, Wiens JJ: Rates and patterns in the evolution of snake-like body form in squamate reptiles: evidence for repeated re-evolution of lost digits and long-term persistence of intermediate body forms. Evolution 2008, 62:2042-2064.

35. Kohlsdorf T, Wagner GP: Evidence for the reversibility of digit loss: a phylogenetic study of limb evolution in Bachia (Gymnophthalmidae: Squamata). Evolution 2006, 60:1896-1912.

36. Lande R: Evolutionary mechanisms of limb loss in tetrapods. Evolution 1978, 32:73-92.

37. Harris PH, Hasso SM, Ferguson MWJ, Fallon JF: The development of Archosaurian First-Generation teeth in a chicken mutant. Curr Biol 2006, 16:371-377.

38. Borowsky R: Restoring sight in blind cavefish. Curr Biol 2008, 18:R23-24

39. Kohlsdorf T, Cummings MP, Lynch VJ, Stopper GF, Takahashi K, Wagner GP: A molecular footprint of limb loss: Sequence variation of the autopodial identity gene Hoxa-13. J Mol Evol 2008, 67:581-593.

40. Hasson P, Del Buono J, Logan MPO: Tbx5 is dispensable for forelimb outgrowth. Development 2007, 134:85-92.
41. Minguillon C, Nishimoto S, Wood S, Vendrell E, Gibson-Brown JJ, Logan MPO: Hox genes regulate the onset of Tbx 5 expression in the forelimb. Development 2012, 139:3180-3188.

42. Kohlhase J, Schubert L, Liebers M, Rauch A, Becker K, Mohammed SN, Newbury-Ecob R, Reardon W: Mutations at the SALL4 locus on chromosome 20 result in a range of clinically overlapping phenotypes, including Okihiro syndrome, Holt-Oram syndrome, and patients previously reported to represent thalidomide embryopathy. J Med Genet 2003, 40:473-478.

43. Hamburger $V$, Hamilton HL: A series of normal stages in the development of the chick embryo. 1951. Dev Dyn 1992, 195:231-272.

44. Nagai H, Mak SS, Weng W, Nakaya Y, Ladher R, Sheng G: Embryonic development of the emu, Dromaius novaehollandiae. Dev Dyn 2011 240:162-175.

45. Sambrook J, Russell DW: Molecular cloning: a laboratory manual. Cold Spring Harbor Laboratory. Vol 1. 3rd Edition. Chapter 6, 2001:p 6.4

46. Huynen L, Millar CD, Scofield RP, Lambert DM: Nuclear DNA sequences detect species limits in ancient moa. Nature 2003, 425:175-178.

47. Cooper A, Poinar HN: Ancient DNA: Do it right or not at all. Science 2000, 289:1139

48. Suzuki T, Ogura T: Congenic method in the chick limb buds by electroporation. Dev Growth Differ 2008, 50:459-465.

49. Suzuki T, Hasso SM, Fallon JF: Unique SMAD1/5/8 activity at the phalanx-forming region determines digit identity. Proc Natl Acad Sci U S A 2008, 105:4185-4190.

50. Murakami M, Nakagawa M, Olson EN, Nakagawa O: A WW domain protein TAZ is a critical coactivator for Tbx5, a transcription factor implicated in Holt-Oram syndrome. Proc Natl Acad Sci U S A 2005, 102:18034-18039.

51. Kawakami Y, Capdevila J, Buscher D, Itoh T, Esteban CR, Izpisua-Belmonte JC: WNT signals control FGF-dependent limb initiation and AER induction in the chick embryo. Cell 2001, 104:891-900.

52. Kulisz A, Simon HG: An evolutionarily conserved nuclear export signal facilitates cytoplasmic localization of the Tbx 5 transcription factor. Mol and Cell Biol 2008, 28:1553-1564.

53. Zaragoza MV, Lewis LE, Sun G, Wang E, Li L, Said-Salman I, Feucht L, Huang T: Identification of the TBX5 transactivating domain and the nuclear localization signal. Gene 2004, 330:9-18.

doi:10.1186/1471-2148-14-75

Cite this article as: Huynen et al:: Reconstruction and in vivo analysis of the extinct $t b \times 5$ gene from ancient wingless moa (Aves: Dinornithiformes). BMC Evolutionary Biology 2014 14:75.

\section{Submit your next manuscript to BioMed Central and take full advantage of:}

- Convenient online submission

- Thorough peer review

- No space constraints or color figure charges

- Immediate publication on acceptance

- Inclusion in PubMed, CAS, Scopus and Google Scholar

- Research which is freely available for redistribution 